regard to his remarks about the lava flows from a crater, though I am by no means an authority upon this subject, such as Dr. Johnston-Lavis, I would beg to point out that the lava from the crater of Skaptar Jokul in the year 1783 formed two main streams which flowed for a distance of forty to fifty miles each, and varied in thickness or depth from 600 to I000 $\mathrm{ft}$. Now I cannot help thinking that such streams, only so much bigger, might have flowed from the craters of the moon, and it is well known that enormous floods have issued from volcanoes in the Sandwich Islands without much eruption of rocky, or pumaceous débris, which might hide the effect of the lava, as Dr. Johnston-Lavis suggests, though Prof. Pickering puts forward the suggestion that it is some material, such as pumice, which we see in the moon's rays. Apart from which geologists tell us that apparently in prehistoric times lava seems to have issued from vertical fissures, and deluged large areas, as is well seen in the great basalt plain of Snake River, Idaho, North America. Assuming that these fissures were caused by the contraction of the earth's outer crust when cooling, and again comparing the moon with the earth, we at least come to Nasmyth's wellknown theory as regards these ray systems, though the manner in which these peculiar phenomena radiate from the craters still seems to suggest to me the same actions which took place from Skaptar Jokul, and in the Sandwich Islands. However, assuming Dr. Johnston-Lavis to be correct in his objections to this theory, I should like to know if he considers Nasmyth's theory any more likely to solve this interesting problem?

Then with reference to the meteorite theory, it seems to me that this scarcely satisfies all the objections. In the first place, these rays are in many cases as wide as ten to twenty miles, and of a very considerable length, and it would take a meteor or other body of excessive size to cause such markings, apart from which the speed would have to be truly prodigious, and, however horizontally the object was approaching the lunar surface, the gravitational attraction, though comparatively slight, would tend to divert the path into a vertical one to some other portion of the surface. Again, it is a curious coincidence that by far the greater number of these rays radiate from the principal craters, and if the meteorite theory is correct, how is it they crossed such a huge-walled crater as Clavius without apparently breaking down its walls, though leaving their marks? The rills and clefts certainly lend themselves to this theory, though when we consider the Sirsalis cleft, 300 miles long, and that there are no fewer than forty in the interior of Gassendi, it becomes difficult to explain even these.

I certainly agree with Dr. Johnston-Lavis, that a practical astronomer with a high-power instrument ought to collaborate with a thoroughly practical vulcanologist, when perhaps some satisfactory explanation would be arrived at. Until then, I am afraid things will have to remain as they are.

C. Hubert Plant.

Lichfield Road, Walsall, February 10.

\section{The Discovery of Australia.}

IN a note in NATURE of November 27, I9I3 (p. 379) relative to the Houtman's Abrolhos Islands, the remark is made:- "The wreck of the Dutch East India Co.'s ship, the Batavia, under the command of Capt. Pelsart, in 1629 , is said to have led to the first recorded discovery of Australia."

Without entering into the vexed question of who first discovered Australia, I may point out that there are records of more than a dozen visits of Dutch ships and one English shio to the northern and NO. 23 I3, VOL. 92] western coasts of Australia before 1629. In fact, the general outline of the whole of the present State of Western Australia and of the Gulf of Carpentaria was known to the Dutch before that date.

The Abrolhos Islands were discovered by the ships Dordrecht and Amsterdam, under the command of Frederik de Houtman, whose name they still bear, in 1619 (vd. Heeres, "The Part Borne by the Dutch in the Discovery of Australia"). They were rediscovered by the ship Tortelduif in 1624 , and the East India Co. recognised their danger to navigation, and had accordingly issued warnings to the commanders of all its vessels before Pelsart sailed from Holland.

From a scientific point of view the wreck of the Batavia is of most interest, because it led to the discovery of the first member of the kangaroo family, viz., the Dama Wallaby, Macropus eugenii, which is plentiful on the two largest islands of the group.

As it is generally supposed that the first discovery of the kangaroo was made by Sir Joseph Banks on Captain Cook's first voyage in 1770 , I think that zoologists may find Pelsart's account of this smaller species, written nearly I50 years earlier, of interest.

He says :- "We found in these islands large numbers of a species of cats, which are very strange creatures; they are about the size of a hare, their head resembling the head of a civet-cat; the forepaws are very short, about the length of a finger, on which the animal has five small nails or fingers, resembling those of a monkey's forepaw. Its two hind legs, on the contrary, are upwards of half an ell in length, and it walks on these only, on the flat of the heavy part of the leg, so that it does not run fast. Its tail is very long, like that of a long-tailed monkey; if it eats, it sits on its hind legs, and clutches its food with its forepaws, just like a squirre! or monkey.

"Their manner of generation or procreation is exceedingly strange and highly worth observing. Below the belly the female carries a pouch, into which you may put your hand; inside this pouch are her nipples, and we have found that the young ones grow up in this pouch with the nipples in their mouths. We have seen some young ones lying there, which were only the size of a bean, though at the same time perfectly proportioned, so that it seems certain that they grow there out of the nipples of the mammæ, from which they draw their food, until they are grown up and are able to walk. Still, they keep creeping into the pouch even when they have become very large, and the dam runs off with them when they are hunted." W. B. Alexander.

The Western Australian Museum and Art Gallery, Perth, Western Australia, January Io.

\section{DAILY SYNOPTIC CHARTS OF \\ THE NORTHERN HEMISPHERE AND ABSOLUTE UNITS.}

$\mathrm{O}^{\mathrm{N}}$ January $\mathrm{I}$ of this year, as already mentioned in the Notes of the issue of Nature for February 5, the Weather Bureau of the United States commenced the issue of a daily weather map of the northern hemisphere, compiled from observations received daily at Washington by telegraph.

In addition to the regular reports from the United States and Canada, represented in the well-known daily weather map of the bureau, reports are obtained from upwards of forty stations, which are sufficiently distributed in latitude and longitude to form the basis of a chart of isobars and isotherms for the northern hemi- 